\title{
ANALYSIS OF POLITENESS STRATEGIES OF JAPANESE WOMAN IN GEISHA MOVIE
}

\author{
Sri Sugiharti \\ English Dept. Unrika \\ srisgihartiwismono@gmail.com
}

\begin{abstract}
This study analyzed of the Geisha movie. This study used brown and Levinson theory of positive politeness (1987). The data of this study use the script of "Geisha" movie. The data found, the writer found out the data 111 of the "Geisha" movie used of positive politeness as suggested by Brown and Levinson (1987). The data applied by using qualitative research.. The objective of the study is to identify the positive politeness Strategy and negative politeness Strategy. The result of the study is the positive politeness Strategy 1, 10 times ( 4,87\% ), Strategy 2,3 times ( 1,46\% ),Strategy 3, 4 times (1,95\% ), Strategy 4, 20 times (9,75),Strategy 5, 4 times (1,95\%), Strategy 6, 12 times (5,85\%), Strategy 7, 4 times ( 1,95\%), Strategy 8, 0 times ( 0$)$, Strategy 9, 4 times ( $1,95 \%)$, Strategy 10, 3 times ( 1,46\%), Strategy 11, 6 times (2,92\%), Strategy 12, 13 times $(6,34 \%$ ), Strategy 13, 20 times (9,75\% ), Strategy 14, 3 times (1,46\% ), and Strategy 15, 14 times ( 6,82\% ). Therefore, the positive politeness mostly frequently was strategy 13 used in the Geisha.
\end{abstract}

\section{Keywords: Positive politeness, Japanese woman, and Geisha}

\begin{abstract}
Abstrak
Penelitian ini dianalisis dari film Geisha. Penelitian ini menggunakan coklat dan teori Levinson kesopanan positif (1987). Penggunaan data ini mempelajari naskah "Geisha" film. Data tersebut ditemukan, penulis menemukan yang data 111 dari "Geisha" film digunakan kesopanan positif seperti yang disarankan oleh Brown dan Levinson (1987). Data tersebut diterapkan dengan menggunakan penelitian kualitatif .. Tujuan dari penelitian ini adalah untuk mengidentifikasi positif dan negatif kesopanan kesopanan Strategi Strategi. Hasil dari penelitian ini adalah kesopanan positif Strategi 1, 10 kali (4,87\%), Strategi 2,3 kali (1,46\%), Strategi 3, 4 kali (1,95\%), Strategi 4, 20 kali (9,75), Strategi 5, 4 kali (1,95\%), Strategi 6, 12 kali (5,85\%), Strategi 7, 4 kali (1,95\%), Strategi 8, 0 kali (0), Strategi 9, 4 kali (1,95\%), Strategi 10, 3 kali (1,46\%), Strategi 116 kali (2,92\%), Strategi 12, 13 kali (6,34\%), Strategi 13, 20 kali (9,75\%), Strategi 14, 3 kali (1,46\%), dan Strategi 15, 14 kali (6.82\%). Oleh karena itu, positif strategi kesantunan 13 sebagian besar sering digunakan dalam Geisha.
\end{abstract}

Kata kunci: kesopanan positif, wanita Jepang, dan Geisha

\section{INTRODUCTION}

In real life human being need each others to fulfil their needs. So, they must communicate to get what they want. Hence, communication is very important for human beings, communication involves two or more people coding and encoding messages to each other through the medium of language. Thus, a language is a crucial tool for human beings to express their desires, moods, feelings, and needs. Therefore, the main function of language is a tool of communication to reach aims and intention. Language is very important in human 
being's life because through language people can communicate with other people all around the world. That's why, language can be called as a means to connect people and give than information about anything. According to Thomas (1980:1-2) the definitions of pragmatics in general include dealing with meaning in use or meaning in context. More specifically, Thomas defines pragmatics as having to do with speaker meaning and utterance interpretation. The concept of speaker meaning was favoured by researchers who took a social view of the disciplines, whereas utterance interpretation was favoured by those who use the cognitive approach. Currently, pragmatics is widely known as one of the branches of linguistics which is concerned with language used to communicate in specific situations and contexts. Parkers (1986:11) stresses that pragmatics is distinct from grammar, in that it is not the study of the internal structure of a language. While Leech (1981) in addition, states that human language is then composed of three components, such as: phonology, which concerns to sounds, syntax, which concerns to grammatical structures, and semantic, which concerns to meaning.

\section{LITERATURE REVIEW}

Brown and Levinson (1987) in addition state when a learner studies a language, they cannot avoid making mistakes. So, it is impossible for human being avoid of misunderstanding when they involved in communication. Brown has also found that mistakes a learner makes are parts of process of constructing a new system of language. Language is a means to give or exchange information like; news, idea, or opinion. Thus, a language has a lot of contribution for human being in expressing their desire, mood, feeling and their needs.

According to Brown and Levinson (1987) when a learner studies a language, they cannot avoid making mistakes. So, it is impossible for human being avoid of misunderstanding when they involved in communication. Brown has also found that mistakes a learner makes are parts of process of constructing a new system of language. Language is a means to give or exchange information like; news, idea, or opinion. Thus, a language has a lot of contribution for human being in expressing their desire, mood, feeling and their needs.

It is to avoid from misunderstanding in communication between a speaker and a listener, there is a study called pragmatics as the way of explaining language in context. Explaining the meaning, it is necessary to know who the speaker and who the listener are, where, and when the time is, and the other aspect of contextual description. Those are used to make the hearer understand what the speaker said. One of the discussions in pragmatic is politeness. Pragmatic studies about linguistic that how the language used to communicate. 
Positive politeness is redress directed to the addressee's positive face. His wants (or the actions, acquisitions, values resulting from them) should be thought of as desirable. Brown, (1987:101). The positive face is to show rationality that everybody wants their face preserved, and everybody wants to be appreciated. Positive politeness is concerned toward face of hearer, the positive self-image that he claims for himself.

According to Brown and Levinson, (1987:70) state that positive politeness is redress directed to addressee's positive face by approving or including the addressee as a friend or a member of a group. In other words, positive politeness is a politeness strategy used to satisfy the positive face of the hearer. It is solidarity oriented. Positive politeness is used by the speaker to give an impression that he/she wants hearer's wants, or in other words, speaker wants the hearer's face to be satisfied.

Positive politeness also used by strangers in the interaction to get closer to the hearer. The positive face is to show rationally that everybody wants their face preserved, and they wants to be appreciated. Thus the hearer needs to respect or face want from the speaker. Positive politeness is used as a kind of social acceleration.

\section{METHODOLOGY}

The writer used qualitative method because the writer will analyze the descriptive data based on the uses conversation of the role in Giesha movie. The purpose qualitative research is not to verify a causal relationship by falsifying a non relationship hypothesis. According to Cresswell (2003:18), a quantitative approach is one in which the investigator primarily uses post positivist claims for developing knowledge (i.e., cause and effect thinking, reduction to specific variables and hypotheses and questions), employs strategies of inquiry such as experiments that yield statistical data. While Sugiyono (2006:9) states that qualitative is research method that is based on the philosophy post positivism, used to examine the condition of natural object. Creswell (2003:181) scrutinizes that qualitative is research takes places in the natural setting, the qualitative researcher often goes to the site (home, office )of the participant to conduct the research. Due to this study uses qualitative method, therefore, the writer will explain how the data will be obtained in this study. The data consist of two types, namely primary data and secondary data.

\section{RESULT}


This part explains the analysis of the data using Brown and Levinson's theory. The data are the utterances of the main characters found in the "Geisha" movie. The characters consist of the Geisha.. The data of this study use the script of "Geisha" movie. From the data that have been analyzed, the writer found out the data 111 times positive politeness of the "Geisha" movie used of positive and negative politeness as suggested by Brown and Levinson (1987).

The positive politeness Strategy 1, 10 times ( 4,87\%), Strategy 2,3 times ( 1,46\% ),Strategy 3, 4 times (1,95\% ), Strategy 4, 20 times (9,75 ),Strategy 5, 4 times (1,95\% ), Strategy 6, 12 times (5,85\%), Strategy 7, 4 times ( $1,95 \%)$, Strategy 8, 0 times ( 0 ), Strategy 9, 4 times ( 1,95\%), Strategy 10, 3 times ( 1,46\%), Strategy 11, 6 times $(2,92 \%)$, Strategy 12, 13 times (6,34\%), Strategy 13, 20 times (9,75\%), Strategy 14, 3 times (1,46\% ), and Strategy 15, 14 times (6,82\%).

In this first strategy, study is in general, this output suggest that Speaker should take notice of aspects of Hearer's condition (noticeable changes, remarkable possessions, anything which look as though hearer would want speaker in this study done by Chyo to give to notice and approve of it). Example used as FTA include in English: a compliment, an offer, or a request.

This strategy 2 is done by Chiyo to communicate to another character in the Movie of Geisha. So, Chiyo gives contributions to the conversation, by 'making a good story'. This may be done by using the 'vivid present' direct speech, taq question, or expressions such as ; this a common feature of positive-politeness conversations, as it pulls $\mathrm{H}$ right into the middle of the events being discussed, metaphorically at any rate, to increase H's interest and to draw him into the conversation. This strategy 4 includes in-group usages of address forms, of language or dialect or slang, and of ellipsis.

This strategy 5 there are two ways to seek agreement, such as safe topics and repetition. Safe topics are used when speaker stresses his agreement with hearer and therefore to satisfy hearer's desire to be right. Agreement may also be stressed by repeating part or some utterances in conversation and by using particles that function to indicate emphatic agreement.

This strategy 7 small talk used by the value of Chiyos spending time and effort on being another character, as a mark of friendship or interest in him, gives rise to the strategy of redressing an FTA by talking for a while about unrelated topics. Chiyo can thereby stress his general interest in $\mathrm{H}$, and indicate that he hasn't come to see characters in the movie 
simply to do the FTA (e.g. a request), even though his intent to do it may be made obvious by his having brought a gift.

This strategy 9 used to indicate that $\mathrm{S}$ and $\mathrm{H}$ to co-operators. Hence $\mathrm{S}$ pushes $\mathrm{H}$ to cooperate with speaker S is to assert or imply knowledge of H's wants and willingness above may sometimes function in this way, This include doing the FTA of offers and requests as many utterances.

This strategy 10 is aimed to may choose to stress his cooperation with hearer in another way. Chiyo may, that is, claim that (within a certain sphere of relevance) whatever hearer wants, Chiyo wants foe another character will help to obtain something. Chiyo gives Offers and promises are the natural outcome of choosing this strategy; even if they are false. Usually this strategy often used in interaction.

This strategy 11 assumes that characters wants Chiyo's wants for s (or for S and $\mathrm{H}$ ) and will help $\mathrm{S}$ to obtain them. It is to simply, hearer makes tacit claim that hearer $\mathrm{H}$ will cooperate with Chiyo and it will be done with mutual shared interests.

This strategy 13 is when speaker gives reasons as to why she wants what she wants. This movie is by including hearer / character thus in his practical reasoning. This is giving reasons is a way of implying 'I can help you' or 'you can help me', and assuming cooperation, a way of showing what help is needed.

\section{CONCLUSION}

This study focused on the Geisha movie. This study used brown and Levinson theory of positive and negative politeness (1987). The data of this study use the script of "Geisha" movie. From the data that have been analyzed, the writer found out the 205 times positive politeness and negative politeness is 94 times of the "Geisha" movie used of positive and negative politeness as suggested by Brown and Levinson (1987). Those will be broken down as follows:

The positive politeness Strategy 1, 10 times ( 4,87\% ), Strategy 2,3 times ( $1,46 \%$ ),Strategy 3, 4 times (1,95\% ), Strategy 4, 20 times (9,75 ),Strategy 5, 4 times (1,95\% ), Strategy 6, 12 times (5,85\%), Strategy 7, 4 times ( $1,95 \%)$, Strategy 8, 0 times ( 0 ), Strategy 9, 4 times ( 1,95\%), Strategy 10, 3 times ( 1,46\%), Strategy 11, 6 times (2,92\% ), Strategy 12, 13 times (6,34\%), Strategy 13, 20 times (9,75\%), Strategy 14, 3 times (1,46\% ), and Strategy 15, 14 times (6,82\%). 
And the negative politeness applied in this study consists of Strategy 1, 2 times $(0,97 \%)$, Strategy 2, 5 times (2,43\% ), Strategy 3, 9 times (4,39\%), Strategy 4, 3 times ( 1,46\% ), Strategy 5, 13 times (6,34\% ), Strategy 6, 2 times (0,97\%), Strategy 7, 13 times $(6,34 \%)$, Strategy 8, 11 times (5,36\% ), Strategy 9,4(1,95\% ), and Strategy 10, 21 times $(10.24 \%)$

It based on the data above that the positive politeness consist of 111 times $(54,14 \%)$ and negative politeness 94 times (45,85\%). Therefore, the positive politeness mostly frequently used in the Geisha.

\section{BIBLIOGRAPHY}

Austin. 1962. How to do with things. Combridge: Combridge University Press.

Brown, Penelope and Stephen C Livinson. 1978, 1987. Politeness : Some Universal in Language Usaga. Cambridge University Press.

Cresswell, D. 2003. Mixed method: Qualitative and quantitative Methods. London: Maxwell.

Leech, G. 1983. Principles of Pragmatics. Essex: Longman House

Holmes, Janet. 1992. An Introduction to Sociolinguistic. New York: Longman.

Kaswanti Purwo, H. Bambang. 1990. A Semantic and Syntactic Study. Malang: IKIP.

Kramsach, C. 1998. Language and culture. London: Oxford University Press.

Levinson, Stephen C. 1983. Pragmatics. London: Cambridge University Press.

Moleong, Lexy J. 1983. Metodologi Penelitian Kualitatif. Jakarta: Depdikbud Press.

Ningsih, Rahayu Istiqomah. 2007. The Analaysis of lanaguage Use in SMS :a Pragmatic approach. Muhammadiyah University of Surakarta. (unpublished)

Renkema, Jan. 1993. Discourse Studies. Amtersdams: John Benjamin Published.

Sugiono. 2004. Metode Penelitian Pendidikan.Jakarta : Alfabeta.

Surachmad, Winarno. 1994. Dasar dan Teknik Research: Pengantar Metodologi Ilmiah. Bandung: CV. Tarsito.

Searle, John. 1975. Speech Acts. Cambridge: Cambridge University Press.

Reiter, Rosina Marquez. 2000. Linguistic Politeness in Britain and Uruguay: A Contrastive Study of Request and Apologies. Amsterdam: John Benjamins Co.

Surachmad, Winarno. 1994. Dasar dan Teknik Research: Pengantar Metodologi Ilmiah. Bandung: CV. Tarsito. 
Wardhaugh, Ronald. 1977. Introduction to Linguistics. Toronto: Mc. Grow Hill Company. Yule, George. 1996. Pragmatics. New York: Oxford Press

\section{INTERNET SOURCES}

http://en.wikipedia.org/wiki/Language

Wikipedia (http:www.en.wikipedia.org/wiki/pragmatics)

(http://www.bil,org/linguistics/grossary/of linguistic terms/what is pragmatic.html) 